\title{
ORIGINALARTICLE
}

\section{Mapping the quantitative trait loci (QTL) for body shape and conformation measurements on BTA1 in Japanese Black cattle}

\author{
Aduli Enoch Othniel MALAU-ADULI, ${ }^{1}$ Tomomi NIIBAYASHI, ${ }^{2}$ Takatoshi KOJIMA, ${ }^{2}$ Kazunaga OSHIMA, ${ }^{2}$ \\ Yasushi MIZOGUCHI ${ }^{3}$ and Masanori KOMATSU ${ }^{1}$ \\ ${ }^{I}$ National Institute of Livestock and Grassland Science, Tsukuba-shi, ${ }^{2}$ National Agricultural Research Center for \\ Western Region, Oda-shi and ${ }^{3}$ Shirakawa Institute of Animal Genetics, Nishigo-mura, Fukushima-ken, Japan
}

\begin{abstract}
The detection and mapping of segregating quantitative trait loci (QTL) that influence withers height, hip height, hip width, body length, chest width, chest depth, shoulder width, lumbar width, thurl width, pin bone width, rump length, cannon circumference, chest girth, abdominal width and abdominal girth at weaning was conducted on chromosomal regions of bovine chromosome one. The QTL analysis was performed by genotyping half-sib progeny of five Japanese Black sires using microsatellite DNA markers. Probability coefficients of inheriting allele 1 or 2 from the sire at specific chromosomal locations were computed. The phenotypic data of progeny were regressed on these probability coefficients in a withincommon-parent regression analysis using a linear model that included fixed effects of sex, parity and season of birth, as well as age as a covariate. F-statistics were calculated every $1 \mathrm{cM}$ on a linkage map. Permutation tests of 10000 iterations were conducted to obtain chromosome-wide significance thresholds. A significant QTL for chest width was detected at $91 \mathrm{CM}$ in family 3. The detection of this QTL boosts the prospects of implementing marker-assisted selection for body conformation traits in Japanese Black beef cattle.
\end{abstract}

KEYWORDS: beef cattle, body shape, conformation, Japanese Black, quantitative trait loci (QTL) mapping.

\section{INTRODUCTION}

Body shape and conformation measurements are useful selection traits in beef cattle because of their positive correlation with liveweight changes and growth (Varade $\delta$ Ali 2001). In dairy cows, body size measurements are very useful in estimating body weight and productivity as demonstrated by the reports of Heinrichs et al. (1992), Enevoldsen and Kristensen (1997), Kertz et al. (1997) and Koenen and Groen (1998). In beef cattle, similar research has been conducted and reported by Gilbert et al. (1993), Vargas et al. (2000) and Magnabosco et al. (2002), but such information in Japanese Black cattle is scanty and limited to performance test and field carcass traits only (Mukai et al. 1995, 2000; Karnuah et al. 2001; Smith et al. 2001; Sosa et al. 2002). There is an abundance of published work on breed, age and sex differences in body measurements in cattle (Cestnik 2001; Rodriguez et al. 2001; Roy et al. 2001; Tozser et al. 2001; Afolayan et al. 2002a,b; Maiwashe et al. 2002). However, to our knowledge, apart from the work of Napolitano et al. (2001) with Italian Chianina' Piemontese crossbred cattle and Ashwell et al. (1998) with US Holsteins, there is no published information on the detection of quantitative trait loci (QTL) for body measurements related to shape and conformation traits in any other

Correspondence: Aduli Enoch Othniel Malau-Aduli, School of Agricultural Science, University of Tasmania, Private Bag 54, Hobart, Tasmania 7001, Australia. (Email: Aduli.MalauAduli@utas.edu.au, aduli40@yahoo.co.uk) Received 10 October 2003; accepted for publication 8 September 2004. 
cattle breed. This justifies the need for the present study by our research into Japanese Black beef cattle.

The mapping of QTL is the first step towards identifying the genes and causal polymorphisms responsible for traits of importance in agriculture (Seaton et al. 2002). The detection of QTL influencing body shape and conformation traits would be useful in the implementation of marker-assisted selection in Japanese Black beef cattle. Comparative mammalian genomics reveal that bovine chromosome 1 (BTAl) is equivalent to the human chromosome 3 (http:// bos.cvm.tamu.edu/htmls/rhbovl.html), which contains growth-regulating genes such as the growth hormone secretagogue receptor also known as ghrelin (Shuto et al. 2002; Hosoda et al. 2003), glycogenin (Mu et al. 2001) and Pit-1 (Ohta et al. 1992; HendriksStegeman et al. 2001). It is therefore justifiable to focus on BTA 1 in a scan for body conformation and growth-related QTL in Japanese Black cattle. Preliminary genome-wide scanning in our laboratory using only 30 animals (unpublished data) had suggested Bos taurus autosomes (BTA) 1,2 and 5 as chromosomes containing segregating QTL that significantly influenced the growth traits in Japanese Black cattle. Therefore, in this confirmatory study with a larger data set of genotyped animals, we report for the first time, the association between microsatellite DNA markers and QTL on BTAl influencing 15 body shape and conformation measurements at weaning in Japanese Black cattle.

\section{MATERIALS AND METHODS}

\section{Animals and management}

One hundred and thirty-two paternal half-sib progeny of five Japanese Black sires produced by artificial insemination at the Department of Livestock and Grassland Science, National Agricultural Research Center for Western Region, Oda, Shimane Prefecture, Japan, were genotyped. Sires 1 and 2 belonged to the line selected for increasing average daily gain and sires 3-5 belonged to the line selected for high beef marbling score. Routine management of the animals involved recording of weight at birth and monthly thereafter, until 18 months of age. Body shape and conformation measurements of withers height, hip height, hip width, body length, chest width, chest depth, shoulder width, lumbar width, thurl width, pin bone width, rump length, cannon circumference, chest girth, abdominal width and abdominal girth were also taken monthly. Calves were allowed to suckle their dams in addition to being fed $1.5 \mathrm{~kg} /$ day per head of concentrate and $1 \mathrm{~kg} /$ day per head of corn silage until 5 months of age when they were weaned. After weaning, they were moved to the grower's barn and continued to be raised on concentrates $(37 \%$ corn grain, $39 \%$ rice bran, $17 \%$ soybean meal, $7 \%$ minerals) and corn silage until 10 months of age. Between 10 and 18 months of age, they were moved to another barn and fed intensively. The proportions of the ration on a dry matter basis were $61 \%$ corn grain, $34 \%$ soybean and corn glutein meal, $2 \%$ bran and 3\% minerals. For every $20 \mathrm{~kg}$ bag, this ration provided an estimated $21 \%$ crude protein, $3.5 \%$ crude fat, $5 \%$ crude fiber, $7 \%$ ash, $0.6 \%$ calcium, $0.40 \%$ phosphate and a total digestible nutrients of $77 \%$. From 18 to 24 months of age, breeding females were returned to the calving barn and the steers were moved to the fattening barn where they were raised primarily on "Mosa meal" a specially formulated fattening ration containing $77 \%$ corn and rye grain, $10.5 \%$ wheat and rice bran, $9 \%$ soybean oil meal and 3.5\% mineral supplement. At all ages, routine veterinary vaccinations and health checks were performed.

\section{Extraction of genomic DNA}

Following the method of Sambrook et al. (1989) and described in detail elsewhere (Malau-Aduli et al. 2003), genomic DNA was extracted and prepared from blood leukocytes and sperm.

\section{Polymerase chain reaction (PCR)}

The PCR premix $(13 \mu \mathrm{L})$ comprised: $10.55 \mu \mathrm{L}$ of distilled water, $1.04 \mu \mathrm{L}$ of $2.5 \mathrm{mmol} / \mathrm{L}$ dNTP mixture (Takara, Shiga, Japan), $1.3 \mu \mathrm{L}$ of 10 'buffer containing $15 \mathrm{mmol} / \mathrm{L} \mathrm{MgCl}_{2}$ and $0.11 \mu \mathrm{L}$ of $25 \mathrm{mmol} / \mathrm{L}$ of $\mathrm{MgCl}_{2}$. A primer $(12.5 \mathrm{pmol} / \mu \mathrm{L})$ of the microsatellite DNA markers, each of which was labeled with one of three different fluorescent labels, FAM, HEX and TET (supplied by the Shirakawa Institute of Animal Genetics, Fukushima, Japan, and based on the bovine genetic map at the US Meat Animal Research Center (Kappes et al. 1997; http://sol.marc.usda.gov)) was added to the PCR premix. Genomic DNA $(1 \mu \mathrm{L}$; $20 \mathrm{ng} / \mu \mathrm{L}$ ) was added, followed by $0.5 \mu \mathrm{L}$ of Taq polymerase enzyme $(0.75$ units $/ \mu \mathrm{L})$ containing $50 \%$ glycerol (Takara). The PCR plates were hotplate-sealed and subjected to PCR in a DNA thermal cycler. The annealing temperature settings were $50^{\circ} \mathrm{C}, 55^{\circ} \mathrm{C}$ and $60^{\circ} \mathrm{C}$. 


\section{Genotyping}

Prior to genotyping, the PCR products were mixed with the markers, which could be genotyped simultaneously in combinations of $4 \mu \mathrm{L}$ of HEX, $1 \mu \mathrm{L}$ of FAM and $1 \mu \mathrm{L}$ of TET, for multiplex genotyping. Next, $0.8 \mu \mathrm{L}$ of the mixed PCR products was added to $4.5 \mu \mathrm{L}$ of DNA size marker, centrifuged for $1 \mathrm{~min}$ at $120 \mathrm{~g}$ and denatured using the PCR machine at a denaturing temperature of $94^{\circ} \mathrm{C}$ for $9 \mathrm{~min}$. The denatured products were subjected to electrophoresis and genotyping in an automated ABI 377 DNA Sequencer. The number of informative microsatellite DNA markers used for the genotyping in each family is shown in Table 1.

\section{Traits analyzed}

Offspring of the five sires born between 1997 and 2002 were evaluated (SAS Institute 2002) for the following body shape and conformation measurements at weaning (5 months of age): withers height, hip height, hip width, body length, chest width, chest depth, shoulder width, lumbar width, thurl width, pin bone width, rump length, cannon circumference, chest girth, abdominal width and abdominal girth.

\section{QTL analysis}

We adopted the methods of Haley and Knott (1992), Knott et al. (1996) and de Koning et al. (1998, 2001) for the detection and mapping of QTL in half-sib populations using least squares simple regression. We used the QTL Express computer program with a web-based user interface (http://qtl.cap.ed.ac.uk/) developed by Seaton et al. (2002) and based on the methods of the previously mentioned researchers for the QTL analysis. The half-sib model of QTL Express run within and across sires, implemented the analysis in a two-step procedure. First, microsatellite DNA marker data on progeny and their common parent (sire) were combined in a multipoint approach to calculate the probabilities of inheriting allele 1 or 2 from the sire at specific chromosomal intervals. These probabilities were combined into coefficients with values between 0.0 and 1.0. Second, the phenotypic data on progeny were regressed on these probability coefficients in a within-common-parent regression analysis. A linear model containing the fixed effects of sire, sex, parity and season of birth as well as age as a covariate, was fitted to the coefficients and phenotypic data. Appropriate F-statistic thresholds for a $P<0.05$ chromosome-wise type 1 error rate were generated by permutation test of 10000 iterations as described by
Churchill and Doerge (1994), Doerge and Churchill (1996) (and applied to other half-sib studies by Spelman et al. 1996 and Vilkki et al. 1997). In determining significant thresholds, the QTL Express software (Seaton et al. 2002) computed both the F-statistic and the $F$-threshold at $P<0.05$ chromosome-wise level. QTL were classified as significant when the F-statistic exceeded the $F$-threshold, indicating a marker-trait association.

\section{RESULTS}

The means and standard deviations of the body conformation measurements at weaning in the five Japanese Black families are shown in Table 2. It was evident that in all families, almost all of the body conformation measurements within traits were similar. The only clearly visible sign of significant differences between families was in the chest girth (CHESTGTH) measurements, which were higher in families 1 and 2 (125.9 and $127.2 \mathrm{~cm}$, respectively) than in families 35 (121.7, 123.4 and $120.2 \mathrm{~cm}$, respectively). Table 1 shows the microsatellite DNA markers that were utilized in genotyping the sires and half-sib progeny and their relative positions on the BTAl map; 18, 23, 11 , 19 and 17 markers were informative for families 1, 2, 3, 4 and 5, respectively.

The estimates of allele substitution of sire QTL effects and locations obtained at the peak of the F-statistics and thresholds of chromosome-wide 5\% significant levels for body shape and conformation traits in the five Japanese Black families are shown in Table 3, and the plot of the F-statistics in groups of five body conformation measurements is shown in Fig. 1. A significant QTL for chest width (CHESTWD) at $91 \mathrm{cM}$ was detected in family 3.

\section{DISCUSSION}

Animal improvement has been achieved by selection based on either phenotype or the predicted additive genetic merit of superior animals for production traits. Molecular biology techniques allow the identification of genetic variation at specific loci and the association between QTL and production traits. The final goal is to use marker-assisted selection to improve the genetic gain achieved by selection as a result of higher accuracy on the estimation of an animal's genetic value (Tambasco et al. 2003). Microsatellites are thought to be the best genome markers and useful ones can be included in marker-assisted selection programs 


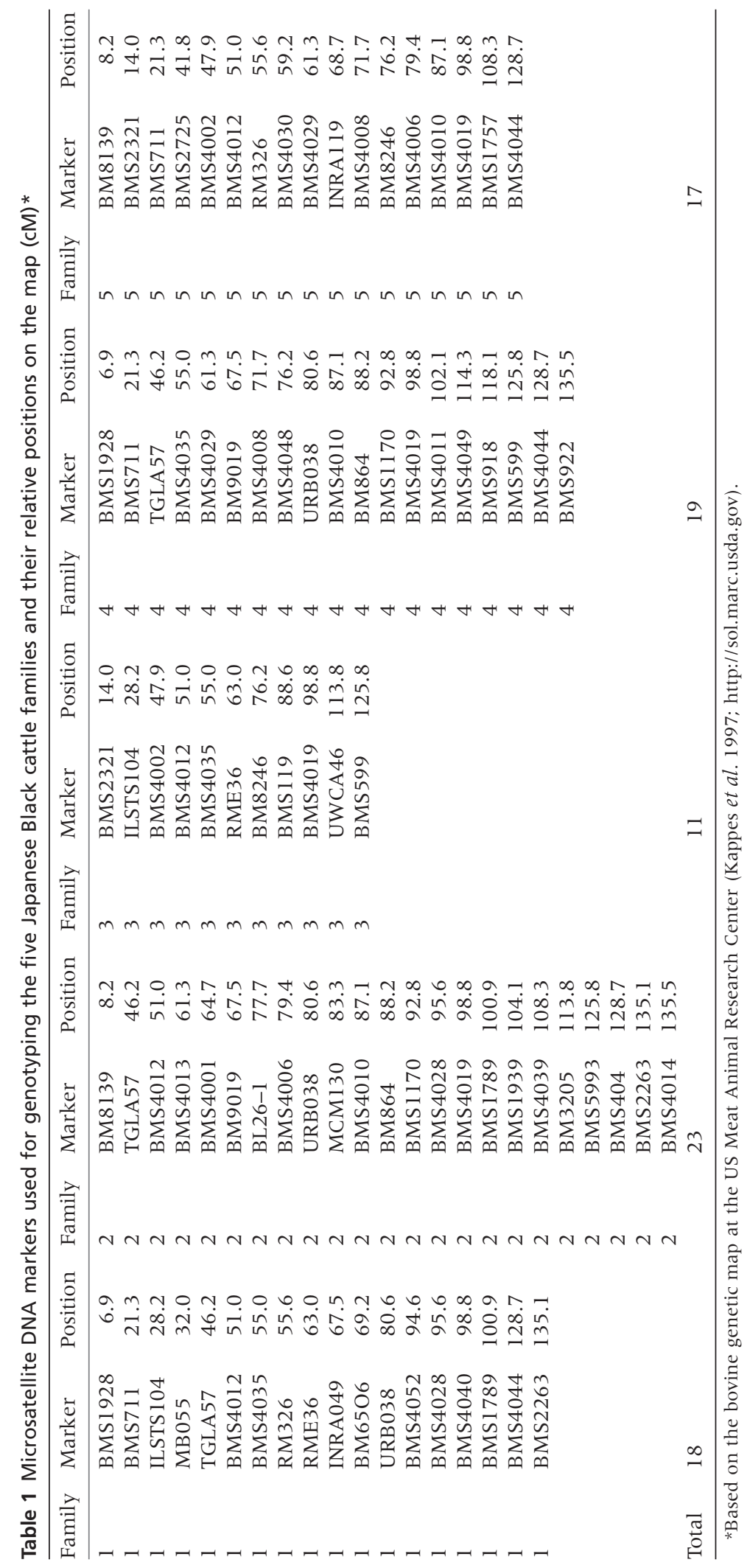


Table 2 Body conformation measurements at weaning (means \pm SD; $\mathrm{cm}$ ) of the progeny of the five Japanese Black sires

\begin{tabular}{|c|c|c|c|c|c|}
\hline Trait & Family 1 & Family 2 & Family 3 & Family 4 & Family 5 \\
\hline Withers height & $99.5 \pm 3.9$ & $100.9 \pm 3.5$ & $98.5 \pm 3.5$ & $97.5 \pm 2.7$ & $97.6 \pm 4.0$ \\
\hline Hip height & $103.1 \pm 3.9$ & $103.0 \pm 3.0$ & $101.0 \pm 3.8$ & $101.1 \pm 3.8$ & $98.7 \pm 4.1$ \\
\hline Body length & $106.5 \pm 5.9$ & $108.1 \pm 5.0$ & $103.2 \pm 7.5$ & $103.2 \pm 4.5$ & $101.9 \pm 5.3$ \\
\hline Chest width & $28.1 \pm 2.2$ & $29.5 \pm 2.3$ & $27.7 \pm 2.6$ & $26.9 \pm 2.2$ & $27.2 \pm 1.6$ \\
\hline Shoulder width & $31.2 \pm 2.6$ & $31.4 \pm 2.1$ & $28.4 \pm 2.2$ & $28.6 \pm 2.0$ & $27.4 \pm 2.3$ \\
\hline Chest depth & $46.3 \pm 1.8$ & $46.6 \pm 1.5$ & $44.7 \pm 1.8$ & $45.5 \pm 1.4$ & $43.8 \pm 2.2$ \\
\hline Hip width & $28.3 \pm 1.8$ & $29.0 \pm 1.3$ & $26.3 \pm 2.1$ & $28.1 \pm 1.4$ & $27.4 \pm 1.5$ \\
\hline Lumbar width & $22.7 \pm 1.5$ & $23.1 \pm 1.0$ & $21.1 \pm 2.1$ & $22.6 \pm 1.3$ & $22.0 \pm 1.3$ \\
\hline Thurl width & $33.0 \pm 2.2$ & $33.6 \pm 1.7$ & $31.0 \pm 1.6$ & $31.3 \pm 1.9$ & $31.0 \pm 2.0$ \\
\hline Pin bone width & $20.5 \pm 2.1$ & $20.6 \pm 1.3$ & $18.6 \pm 1.9$ & $18.9 \pm 1.0$ & $18.1 \pm 1.4$ \\
\hline Rump length & $35.2 \pm 2.1$ & $35.8 \pm 1.8$ & $34.6 \pm 1.7$ & $35.3 \pm 1.4$ & $34.4 \pm 1.7$ \\
\hline Cannon circumference & $14.4 \pm 0.9$ & $14.7 \pm 0.9$ & $13.8 \pm 1.0$ & $13.5 \pm 0.8$ & $13.4 \pm 0.9$ \\
\hline Chest girth & $125.9 \pm 5.2^{\mathrm{a}}$ & $127.2 \pm 4.3^{a}$ & $121.7 \pm 4.9^{\mathrm{b}}$ & $123.4 \pm 3.8^{\mathrm{b}}$ & $120.2 \pm 5.9^{b}$ \\
\hline Abdominal width & $37.0 \pm 2.5$ & $37.7 \pm 2.5$ & $35.4 \pm 2.9$ & $36.5 \pm 2.2$ & $35.5 \pm 1.9$ \\
\hline Abdominal girth & $144.0 \pm 7.0$ & $143.5 \pm 6.1$ & $138.5 \pm 7.4$ & $140.6 .0 \pm 6$ & $138.0 \pm 7.2$ \\
\hline No. of progeny & 40 & 36 & 19 & 17 & 20 \\
\hline
\end{tabular}

Means in rows bearing different superscripts significantly differ between families.

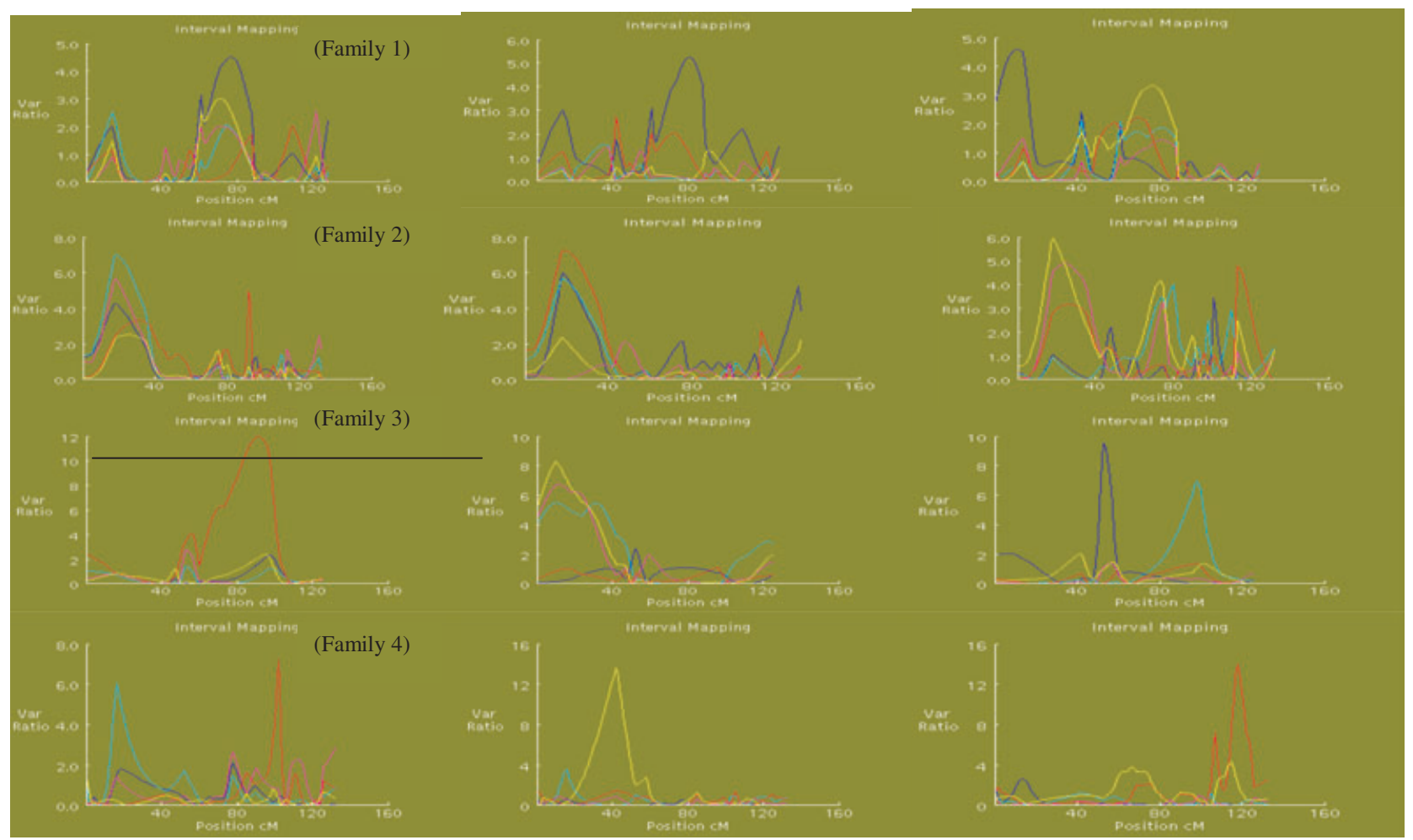

WHT HIPHT BL CHESTWD SHOUWD

CHESTDP HIPWD LUMBWD THURLWD PINBWD

RUMPL CANCIR CHESTGT ABDWD ABDGI

Fig. 1 Map of the F-statistics depicting the positions of quantitative trait loci (QTL) of body conformation traits in Japanese Black cattle. A QTL for CHESTWD at $91 \mathrm{cM}$ reached chromosome-wide significance $(P<0.05)$ in family 3 only (threshold in bold).

to increase the rate of genetic progress (Georges et al. 1993). Napolitano et al. (1996) reported the localization of three microsatellites, IDVGA-2, IDVGA-3 and IDVGA-46, on bovine chromosomes 2, 11 and 19, respectively, and their association with beef performance traits in Fl Piemontese Chianina crossbred cows. Of the three microsatellites, IDVGA-46 was reported to be the best marker for most 


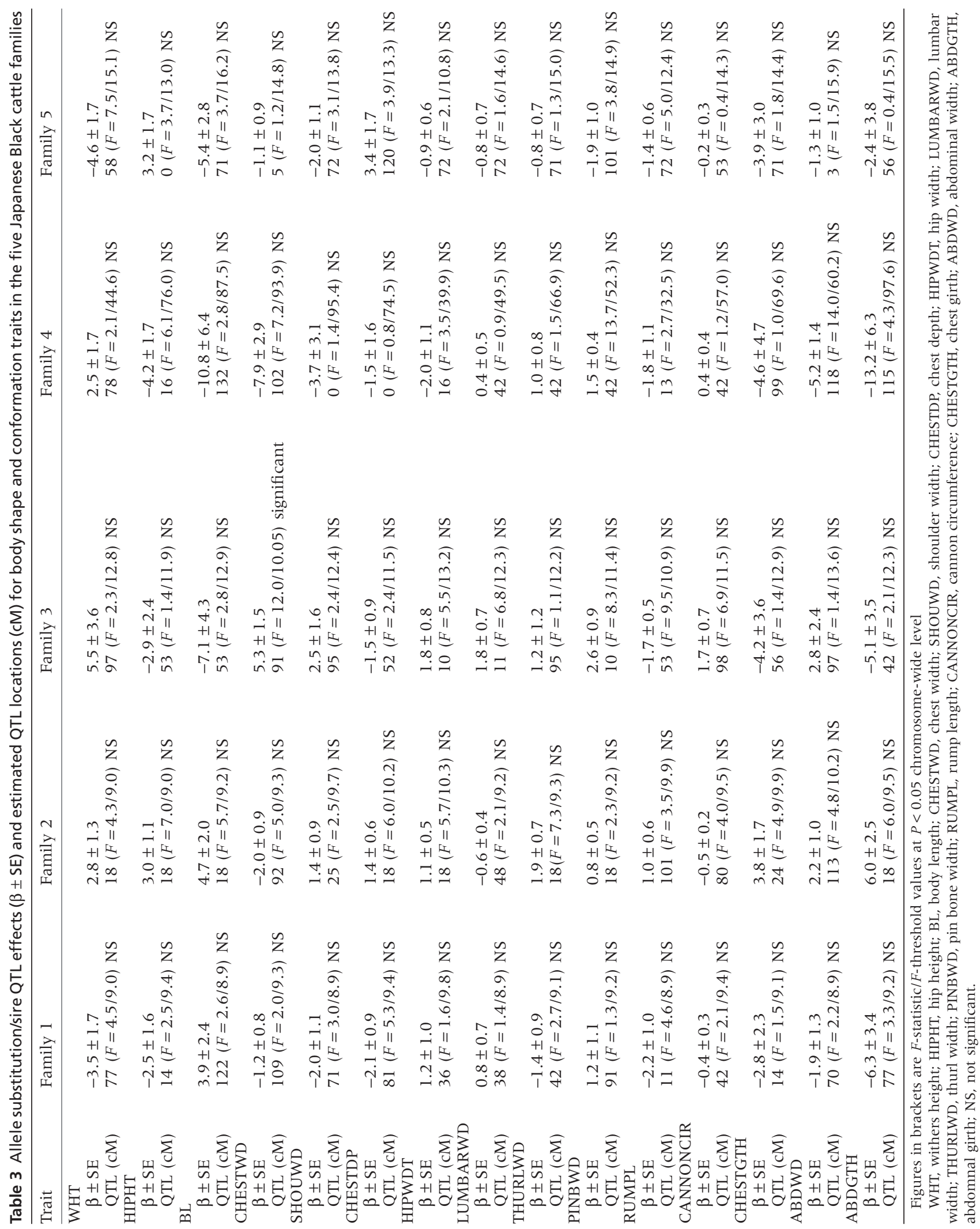


conformational traits in this crossbred population, and that animals homozygous for allele 205 gave the best results in terms of linkage with the segregating QTL for beef conformation (Napolitano et al. 2001). Their study examined only seven body conformation measurements: withers height, body length, chest width, chest depth, chest girth, rump length and pelvis width, whereas we examined 15 measurements and detected a significant QTL for CHESTWD located at $91 \mathrm{cM}$. The implication is that the microsatellite markers BMS 119 and BMS4019 flanking this interval can be used in marker-assisted selection to introduce or retain the beneficial QTL allele. The phenomenon of genetic linkage means that each marker can be used to follow the inheritance of a section of the linked chromosome. However, markers have to be very closely linked to the causative mutation in the trait gene if they are to remain associated with specific QTL alleles through several generations of selection and therefore be useful in practical breeding programs. If a genetic marker and a trait are significantly linked, as portrayed in our study, there is a tendency for such associations to be maintained at a population level. This phenomenon of linkage disequilibrium could be exploited to locate the trait genes using single nucleotide polymorphisms (SNP), which is when two DNA sequences differ by a single base. There is ongoing work in our laboratory to confirm or dispute the presence of significant QTL for body conformation and growth on BTA2 and BTA5. It is our goal to utilize positional cloning using the candidate gene approach to identify the underlying mutation linked to the QTL detected in the present study.

There were significant differences between families in CHESTGTH measurements, for which families 1 and 2 were had higher results than families 3-5, which was not entirely surprising because sires 1 and 2 had been selected for average daily gain (daily gain line) whereas sires 3-5 belonged to the beef marbling score line. Chest girth is an important body conformation measurement that has been reported in Japanese Black cattle. Mukai et al. (1995) studied the genetic relationships between body measurements, growth and field carcass performance traits and reported highly significant and positive genetic correlations between CHESTGTH and carcass weight at the beginning, middle and end of performance testing of 0.64 , 0.77 and 0.79 , respectively. They concluded that it was possible to improve total merit of the carcass by introducing CHESTGTH into performance testing of Japanese Black cattle. Other studies (Oyama et al. 1996; Kitamura et al. 1999) on genetic relationships among recorded body measurement traits, reproductive traits of breeding females and carcass traits in Japanese Black cattle buttress the finding of Mukai et al. (1995) that there is an unfavorable or low correlation between CHESTGTH and beef marbling score $(-0.07$, 0.28 and 0.21 at the beginning, middle and end of performance testing, respectively). It is this low correlation that was also observed in this present study with the beef marbling score families having lower CHESTGTH measurements than the daily gain line families. Other body conformation measurements, such as chest depth, thurl width and withers height, were also found to be genetically correlated with field carcass weight, ranging from 0.64 to 0.90 (Mukai et al. 1995), indicating that body conformation measurements can be valuable in selection for meat quality as well. Unpublished data from our group show a significant and positive relationship between body conformation measurements and average daily gain to weaning and yearling age. Thus, the identification of a significant QTL for CHESTWD in the present study gives hope for the utilization of markers closely linked to this trait for the implementation of marker-assisted selection for growth and carcass traits.

In conclusion, the presence of a QTL on BTAl located at $91 \mathrm{cM}$ between the markers BMS119 and BMS4019 significantly segregating for CHESTWD in Japanese Black cattle has been demonstrated. The detection of this significant QTL boosts the prospect of implementing marker-assisted selection for body conformation traits in the breed. Furthermore, this finding could pave the way for positional cloning using candidate genes in Japanese Black cattle such as ghrelin, glycogenin or Pit-1. The prospect of subsequently isolating and characterizing the genes using single nucleotide polymorphisms (SNP) appears promising.

\section{ACKNOWLEDGMENTS}

This research was conducted when the senior author was at the Laboratory of Animal Breeding and Reproduction, National Agricultural Research Center for Western Region (WeNARC), Oda, Shimane Prefecture, Japan as a postdoctoral research fellow and we extend our appreciation to the Director of WeNARC. We are grateful to the Japan Society for the Promotion of Science for awarding a Post-Doctoral Research Fellowship in Bovine QTL Mapping to Dr A. E. O. MalauAduli. We thank Dr Yoshinori Sugimoto, Director of the Shirakawa Institute of Animal Genetics, Fukushima, for supplying us with the primer sets and we 
thank the Livestock Improvement Association of Japan Incorporated Tokyo, for supplying us with semen and sire blood samples. Our appreciation goes to Dr George Seaton of the Institute of Cell and Animal Population Biology, The University of Edinburgh, Scotland, for his useful advice on QTL Express.

\section{REFERENCES}

Afolayan RA, Pitchford WS, Weatherly AW, Bottema CDK. 2002a. Genetic variation in growth and body dimensions of Jersey and Limousin cross cattle. 1: Pre-weaning performance. Asian-Australasian Journal of Animal Science 15, 1371-1377.

Afolayan RA, Pitchford WS, Weatherly AW, Bottema CDK. 2002 b. Genetic variation in growth and body dimensions of Jersey and Limousin cross cattle. 2: Post-weaning dry and wet season performance. Asian-Australasian Journal of Animal Science 15, 1378-1385.

Ashwell MS, Da Y, VanRaden PM, Rexroad CE, Miller RH. 1998. Detection of potential loci affecting conformation type traits in an elite US Holstein population using microsatellite markers. Journal of Dairy Science 81, 1 120-1 125.

Cestnik V. 2001. An interesting possibility of saving Istrian cattle from extinction. Veterinarska Stanica 32, 163-166.

Churchill GA, Doerge RW. 1994. Empirical threshold values for quantitative trait mapping. Genetics 138, 963-971.

de Koning DJ, Visscher PM, Knott SA, Haley CS. 1998. A strategy for QTL detection in half-sib populations. Animal Science 67, 257-268.

de Koning DJ, Schulmant NF, Elo K, Moisio S, Kinos R, Vilkki J, Maki-Tanila A. 2001. Mapping of multiple quantitative trait loci by simple regression in half-sib designs. Journal of Animal Science 79, 616-622.

Doerge RW, Churchill GA. 1996. Permutation tests for multiple loci affecting a quantitative character. Genetics 142, 285-294.

Enevoldsen C, Kristensen T. 1997. Estimation of body weight from body size measurements and body condition scores in dairy cows. Journal of Dairy Science 80, 1988-1995.

Georges M, Dietz AB, Mishra A, Nielsen D, Sargent LS, Sorensen A, Steele MR, Zhao X, Leipold H, Womack JE, Lathrop M. 1993. Microsatellite mapping of the gene causing weaver disease in cattle will allow the study an associated quantitative trait locus. Proceedings of the National Academy of Sciences USA 90, 1058-1062.

Gilbert RP, Bailey DR, Shannon NH. 1993. Linear body measurements of cattle before and after twenty years of selection for postweaning gain when fed two different diets. Journal of Animal Science 71, 1712-1720.

Haley CS, Knott SA. 1992. A simple regression method for mapping quantitative trait loci in line crosses using flanking markers. Genetics 132, 1211-1222.

Heinrichs AJ, Rogers GW, Cooper JB. 1992. Predicting body weight and wither height in Holstein heifers using body measurements. Journal of Dairy Science 75, 3576-3581.

Hendriks-Stegeman BI, Augustijn KD, Bakker B, Holthuizen P, van der Vliet PC, Jansen M. 2001. Combined pituitary hormone deficiency caused by compound heterozygosity for two novel mutations in the POU domain of the PIT1/ POUlFl gene. Journal of Clinical Endocrinology and Metabolism 86, 1545-1550.

Hosoda H, Kojima M, Mizushima T, Shimizu S, Kangawa K. 2003. Structural divergence of human ghrelin: identification of multiple ghrelin-derived molecules produced by post-translational processing. Journal of Biological Chemistry 278, 64-70.

Kappes SM, Keele JW, Stone RT, McGraw RA, Sonstegard TS, Smith TPL, Lopez-Corrales NL, Beattie CW. 1997. A second generation linkage map of the bovine genome. Genome Research 7, 235-249.

Karnuah AB, Moriya K, Nakanishi N, Nade T, Mitsuhashi T, Sasaki Y. 2001. Computer image analysis for prediction of carcass composition from cross-sections of Japanese Black steers. Journal of Animal Science 79, 2851-2856.

Kertz AF, Reutzel LF, Barton BA, Ely RL. 1997. Body weight, body condition score and wither height of prepartum Holstein cows and birth weight and sex of calves by parity: a database and summary. Journal of Dairy Science $\mathbf{8 0}$, 525-529.

Kitamura C, Yasuda Y, Kobayashi T, Nomura T, Shimada K. 1999. Genetic analysis of direct and maternal effects for calf market and carcass weights in Japanese Black cattle. Asian-Australasian Journal of Animal Science 12, 843-845.

Knott SA, Elsen JM, Haley CS. 1996. Methods for multiple marker mapping of quantitative trait loci in half-sib populations. Theoretical and Applied Genetics 93, 71-80.

Koenen EP, Groen AF. 1998. Genetic evaluation of body weight of lactating Holstein heifers using body measurements and conformation traits. Journal of Dairy Science 81, 1709-1713.

Magnabosco DU, Ojala M, De los Reyes A, Sainz RD, Fernandes A, Famula TR. 2002. Estimates of environmental effects and genetic parameters for body measurements and weight in Brahman cattle raised in Mexico. Journal of Animal Breeding and Genetics 119, 221-228.

Maiwashe AN, Bradfield MJ, Theron HE, van Wyk JB. 2002. Genetic parameter estimates for body measurements and growth traits in South African Bonsmara cattle. Livestock Production Science 75, 293-300.

Malau-Aduli AEO, Niibayashi T, Kojima T, Oshima K, Mizoguchi Y, Sugimoto Y, Komatsu M. 2003. Microsatellite DNA marker mapping of bovine chromosome one for QTL affecting birth weight and preweaning growth in Japanese Black cattle (Wagyu). In: Linda H (ed.), 50 Years of DNA: Proceedings of the Association for the Advancement of Animal Breeding and Genetics; Vol. 15, Melbourne, Australia. pp. 14-17. Animal Genetics and Breeding Unit, University of New England, Armidale, Australia.

Mu J, Skurat AV, Roach PJ. 2001. Glycogenin-2: a novel selfglucosylating protein involved in live glycogen biosynthesis. Journal of Biological Chemistry 276, 14532-14539.

Mukai F, Oyama K, Kohno S. 1995. Genetic relationships between performance test traits and field carcass traits in Japanese Black cattle. Livestock Production Science 44, 199_ 205.

Mukai F, Yamagami A, Anada K. 2000. Estimation of genetic parameters and trends for additive, direct maternal genetic effects for birth and calf market weights in Japanese Black beef cattle. Animal Science Journal 71, 462-469. 
Napolitano F, Leone P, Puppo S, Moioli BM, Pilla F, Comincini S, Ferretti L, Carretta A. 1996. Exploitation of microsatellites as genetic markers of beef performance traits in Piemontese $\times$ Chianina crossbred cattle. Journal of Animal Breeding and Genetics 113, 157-162.

Napolitano F, Catillo G, Lucioli S, Carretta A, Di Giacomo A, Rossi G, Moioli BM. 2001. Evidence for quantitative trait locus for conformation traits on chromosome 19 in beef cattle. Journal of Animal Breeding and Genetics 118, 119-124.

Ohta K, Nobukuni Y, Mitsubuchi H, Ohta T, Tohma T, Jinno Y, Endo F, Matsuda I. 1992. Characterisation of the gene encoding human pituitary-specific transcription factor, Pit-1. Gene 122, 387-388.

Oyama K, Mukai F, Yoshimura T. 1996. Genetic relationships among traits recorded at registry judgement: reproductive traits of breeding females and carcass traits of fattening animals in Japanese Black cattle. Animal Science and Technology (Japan) 67, 511-518.

Rodriguez M, Fernandez G, Silveira C, Delgado JV. 2001. Ethnic study of Uruguayan Creoli bovine. 1: Biometric analysis. Archivos de Zootecnia 50, 113-118.

Roy PK, Saha RC, Singh RB. 2001. Influence of body weight at calving and body measurements on various economic traits of Jersey crossbreds maintained under hot humid conditions of West Bengal. Indian Journal of Dairy Science 54, 53-56.

Sambrook J, Fritsch EF, Maniatis T. 1989. Molecular Cloning: A Laboratory Manual, 2nd edn. Cold Spring Harbor Laboratory Press, New York, USA.

Seaton G, Haley CS, Knott SA, Kearsey M, Visscher PM 2002. QTL express: mapping quantitative trait loci in simple and complex pedigrees. Bioinformatics 18, 339-340.

Shuto Y, Shibasaki T, Otagiri A, Kuriyama H, Ohata H, Tamura H, Kamegai J, Sugihara H, Oikawa S, Wakabayashi I. 2002. Hypothalamic growth hormone secretagogues receptor regulates growth hormone secretion, feeding and adiposity. Journal of Clinical Investigation 109, 1429-1436.

Smith SB, Zembayashi M, Lunt DK, Sanders JO, Gilbert CD. 2001. Carcass traits and microsatellite distributions in offspring of sires from three geographical regions of Japan. Journal of Animal Science 79, 3041-3051.

Sosa JM, Senger PL, Reeves JJ. 2002. Evaluation of American Wagyu sires for scrotal circumference by age and body weight. Journal of Animal Science 80, 19-22.

Spelman RJ, Coppieters WL, Karim A, van Arendok JAM, Bovenhuis H. 1996. Quantitative trait loci analysis for five milk production traits on chromosome six in the Dutch Holstein-Friesian population. Genetics 144, 17991808.

Statistical Analysis System (SAS) Institute. 2002. Statistical Analysis System. SAS Institute, Cary, NC, USA.

Tambasco DD, Paz CC, Tambasco-Studart M, Pereira AP, Alencar MM, Freitas AR, Coutinho LL, Packer IU, Regitano LCA. 2003. Candidate genes for growth traits in beef cattle crosses Bos taurus' Bos indicus. Journal of Animal Breeding and Genetics 120, 51-56.

Tozser J, Domokos Z, Alfoldi L, Hollo G, Rusznak J. 2001. Body measurements of cows in a Charolais herd with different genotypes. Allattenyesztes Es Takarmanyozas 50, $15-$ 22.

Varade PK, Ali SZ. 2001. Body measurements on nondescript bullocks of Buldhana District in Maharashtra. Journal of Applied Zoological Research 12, 71-72.

Vargas CA, Elzo MA, Chase CC, Olson TA. 2000. Genetic parameters and relationships between hip height and weight in Brahman cattle. Journal of Animal Science 78, 3045-3052.

Vilkki HJ, de Koning DJ, Elo KT, Velmala RJ, Maki-Tanila AV. 1997. Multiple marker mapping of quantitative trait loci of Finnish dairy cattle by regression. Journal of Dairy Science 73, 2525-2537. 